\title{
Volatile Compounds, Profiles of Virgin Olive Oils Produced In the Eastern Morocco: Oxidative Stability and Sensory Defects
}

\author{
Karima Tanouti ${ }^{1}$, Hanae Serghini-Caid ${ }^{1}$, Marianne Sindic ${ }^{2}$, Jean-Paul Wathelet ${ }^{3}$, Amina Bouseta ${ }^{4} \&$ Ahmed \\ Elamrani ${ }^{1}$ \\ 1 "LBPM" Laboratory of Biology of Plants and Microorganisms, Faculty of Sciences, UMP, Oujda, Morocco \\ ${ }^{2}$ Unit of Analysis, Quality and Risk, Laboratory of Quality and Security of Agrifood Products (QSPA), \\ University of Liège, Gembloux Agro-Bio Tech, Belgium \\ ${ }^{3}$ Department of Chemistry and bio Industries, Unit of General and Organic Chemistry, University of Liège, \\ Gembloux Agro-Bio Tech, Belgium \\ ${ }^{4}$ Departement of Biology, Faculty of Sciences Dhar El Mahraz, USMBA, Fès, Morocco \\ Correspondence: Karima Tanouti, "LBPM”, Faculty of Sciences, BP 717, University Mohamed Premier, Oujda \\ 60000, Morocco. Tel: 212-663-606-325. E-mail: tanoutikarima1@yahoo.fr
}

Received: August 16, 2012 Accepted: September 28, 2012 Online Published: October 29, 2012

doi:10.5539/jfr.v1n4p194 URL: http://dx.doi.org/10.5539/jfr.v1n4p194

This work was carried out with the support of the University Commission for Development (CUD, Belgium): Axe food UMP-02 Program Co-UMP CUD.

\begin{abstract}
Studies on flavor profiles of virgin olive oil (VOO) are becoming more and more numerous. The VOO aromas are determined by a mixture of chemicals in olive oil, which influence its quality. Various studies around the world have shown that the volatile compounds in VOO depend on the climate, cultivation and process.

The present work is a first approach to compare volatile profiles of VOO largely produced in eastern of Morocco after 6 months of storage at ambient temperature in darkness. Oxidative stability measured by Rancimat method at $101^{\circ} \mathrm{C}$ was also determined. VOO volatile profiles were examined using the solid-phase micro extraction fibre method (SPME) in conjunction with gas chromatography/mass spectrometer (GC/ MS). 84 volatile compounds were identified; they belong to various chemical classes, such as aldehydes, alcohols, esters, ketones, carboxylic acids and hydrocarbons. The main volatile compounds present in olive oil samples were compounds with 6 carbon atoms (C6) such as Hexanal, (E)-hex-2-enal, Z-3-Hexen-1-ol and 1-Hexanol. Ethanol and Z-3, 7-dimethyl-1, 3, 6-octatriene, methyl acetate and ethyl acetate were also found. In general, these compounds have been identified in all VOO analyzed samples. The chemical compositions of the analyzed virgin olive oil headspaces evidenced that the most representative compounds In Isly and Kenine were carboxylic acids accounted for $59.24 \%-49.7 \%$ respectively, whereas the volatile fraction of the oil from Achajara almoubaraka showed significantly higher amounts of the alcohols (46\%). Concerning oxidative stability, Isly and Kenine OO, have lower stability values compared to Achajara almoubaraka. Their potential oxidative susceptibility is therefore much higher than Achajara almoubaraka.
\end{abstract}

Keywords: virgin olive oil, volatile compounds, SPME, GC/MS, oxidative stability

\section{Introduction}

Olive oil is a fundamental ingredient in the Mediterranean diet. Besides the cardiovascular protective properties, this product is especially appreciated for its taste and special aromas.

The unique and delicate flavor of the VOO is attributed to the presence of the volatile compounds, which are mainly produced by oxidation of fatty acids through a chain of enzymatic reactions known as the lipoxygenase (LOX) pathways (Angerosa \& Basti, 2001; Kalua et al., 2007). The (LOX) involves a series of enzymes that oxidize (lipoxygenase) and cleave (hydroperoxide lyase) polyunsaturated fatty acids to produce aldehydes. These latter are reduced to alcohols (by alcohol dehydrogenase) and afterward esterified to yield esters (by alcohol acyl transferase) (Kalua et al., 2007). During the extraction of the VOO, the lipoxygenase pathway is initiated by the 
crushing and continues during malaxation. The volatile compounds formed during these operations result from the activity of enzymes of all lipoxygenase pathways and contribute to the final flavor of the VOO. Levels can be modified by the conditions of crushing and malaxation used and depend on the level and the activity of enzymes involved in the various pathways (Angerosa, 2002; Angerosa \& Basti, 2001; Angerosa, Basti, \& Vito, 1999). Yet, other factors that influence the evolution of volatile compounds, responsible for aromas, are fruit maturity, irrigation, extraction methods, storage and condition of the fruit at harvest, cultivar and geographic region (Aparicio \& Morales, 1998; Ben Temime Campeol, Cioni, Daoud, \& Zarrouk, 2006; Diego, Gonzalez, \& Aparicio, 2010; Garcia-Gonzalez, Aparicio-Ruiz, \& Aparicio, 2009; Gomez-Rico, Salvador, La Greca, \& Fregapane, 2006; Haddada et al., 2007; Inarejos-Garcia, Gómez-Rico, Salvador, \& Fregapane, 2010a; Koprivnjak, Procida, \& Zelinotti, 2000; Venkateshwarlu, Meyer, \& Jacobsen, 2004). The levels of major volatile components decreased in the course of ripening but were higher in irrigated olive trees (Gomez-Rico et al., 2006).

The major volatile compounds responsible for VOO aromatic notes are the C6 and the C5 volatile compounds (Angerosa, 2002; Kiritsakis, Nanos, Polymenoupoulos, Thomai, \& Sfakiotakis, 1998) formed from C18 unsaturated fatty acids (oleic, linoleic and linolenic acids) through a chain of enzymatic reactions of the lipoxygenase (LOX) pathway (Angerosa, 2002; Kalua et al., 2007; Kiritsakis et al., 1998). The aroma of olive oil is attributed to a large number of chemical compounds of different chemical classes, aldehydes, alcohols, esters, hydrocarbons, ketones, furans and, probably, other as yet unidentified volatile compounds (Kalua et al., 2007; Kiritsakis et al., 1998; Vichi, Pizzale, Conte, Buxaderas, \& Lopez-Tamames, 2003a). Furthermore, it is well established that aliphatic C6 compounds (aldehydes, alcohols and their corresponding esters) are the most abundant compounds of virgin olive oil (VOO) aroma (Angerosa et al., 1999; Angerosa, Mostallino, Basti, \& Vito, 2000). They mainly contribute to its green odour notes (Dhifi et al., 2005; Guth \& Grosh, 1991; Morales, Calvente, \& Aparicio, 1996).

It is generally agreed that endogenous plant enzymes, through the lipoxygenase pathway (LOX) are responsible for the positive aroma perceptions in VOO. Whereas, chemical oxidation and exogenous enzymes, usually from microbial activity, are responsible for the off-flavor referred to as oxidative rancidity (Angerosa \& Basti, 2001; Kalua et al., 2007; Morales, Rios, \& Aparicio, 1997). This disagreeable sensory note is especially perceptible in oils that are strongly oxidized due to incorrect or excessively long storage and cause the consumers to reject such products (Bendini, Cerretani, Salvador, Fregapane, \& Lercker, 2010; Villière \& Genot, 2006). The absence of the C6 aldehydes, alcohols and esters from the lipoxygenase pathway and the presence of many saturated and unsaturated aldehydes from chemical oxidation, including hexanal, C5 branched aldehydes and alcohols and some C8 ketones, in relatively high concentrations, in the aroma of virgin olive oil, is associated with unpleasant notes (Angerosa, 2000; Gomes da Silva, Costa Freitas, Cabrita, \& Garcia, 2012; Ha, Nihei, \& Kubo, 2004; Kalua et al., 2007). Chemical oxidation is responsible for the formation of off- flavor compounds, such as pent-2-enal and hept-2-enal. The off- flavor compounds associated with unpleasant sensory notes can be assembled in five classes- fusty, moistness- humidity, winey- vinegary, metallic and rancid (Angerosa, 2002; Escuderos, Uceda, Sánchez, \& Jiménez, 2007; Faria, Cárdenas, G-Mesa, Hernández, \& Valcárcel, 2007; Kalua et al., 2007; Morales et al., 1997; Morales, Luna, \& Aparicio, 2005).

Solinas, Angerosa \& Cucurachi (1987) found that the concentrations of the aldehydes E-2-pentenal, hexanal and $E$-2-heptenal, nonanal, 2-heptenal and 2-decenal, increase considerably in the oxidized oils. The authors suggested using E-2-heptenal as a marker for oxidation rather than E-2-pentenal and hexanal, since these two compounds are already present in the aroma of extra virgin olive oils (Bendini et al., 2010). On the other hand Kalua, Bedgood, Bishop and Prenzler (2006) demonstrated that all volatile compounds found in fresh oil decreased during storage in the light in the presence of oxygen, particularly $E$-2-hexenal. The major compounds indicated by different researchers as markers of virgin olive oil oxidation, their sensory characteristics and odor thresholds are reported in (Table 1). 
Table 1. Compounds indicated as markers of off-flavor of virgin olive oil oxidation, their sensory properties, odor thresholds and related references

\begin{tabular}{|c|c|c|c|}
\hline Compounds & Sensory caracteristics & $\begin{array}{l}\text { Odor threshold } \\
(\mathrm{mg} / \mathrm{kg})\end{array}$ & References \\
\hline Octane & sweet & 0.94 & Morales et al., 2005 \\
\hline hexanal & $\begin{array}{l}\text { Fatty, powerful, oily, } \\
\text { grassy }\end{array}$ & 0.32 & Kochhar, 1993; Meijboom, 1964 \\
\hline Octanal & $\begin{array}{l}\text { Fatty, soapy, sharp, } \\
\text { citrus }\end{array}$ & 0.32 & $\begin{array}{l}\text { Morales et al., } 2005 \\
\text { Kochhar, 1993; Meijboom, } 1964\end{array}$ \\
\hline Nonanal & $\begin{array}{l}\text { Fatty, Waxy, paint, } \\
\text { soapy, citrus }\end{array}$ & 0.15 & $\begin{array}{l}\text { Guth \& Grosh, } 1991 \\
\text { Morales et al., } 2005\end{array}$ \\
\hline & & 13.5 & Kochhar, 1993; Meijboom, 1964 \\
\hline E-2-pentenal & Paint, apple & 0.3 & $\begin{array}{l}\text { Servili et al., } 2001 \\
\text { Morales et al., } 2005\end{array}$ \\
\hline E-2-heptenal & $\begin{array}{l}\text { Oxydized, tallowy, } \\
\text { pungent }\end{array}$ & 0.05 & $\begin{array}{l}\text { Morales et al., } 2005 \\
\text { Kochhar, 1993; Meijboom, } 1964\end{array}$ \\
\hline E-2-decenal & Paint, fishy, fatty & 0.01 & $\begin{array}{l}\text { Morales et al., } 2005 \\
\text { Kochhar, 1993; Meijboom, } 1964\end{array}$ \\
\hline Pentanal & Woody, bitter, oily & 0.24 & Kochhar, 1993; Meijboom, 1964 \\
\hline 2,4-heptadienal & $\begin{array}{l}\text { Fatty, nutty, rancid, } \\
\text { cinnamon }\end{array}$ & 3.62 & $\begin{array}{l}\text { Ullrich \& Grosh, } 1988 \\
\text { Morales et al., } 2005 \\
\text { Kochhar, 1993; Meijboom, } 1964\end{array}$ \\
\hline Undecenal & Fatty, tallowy & n.d. & Kochhar, 1993; Meijboom, 1964 \\
\hline Heptanal & $\begin{array}{l}\text { Oily, fatty, heavy, } \\
\text { woody, penetrating, } \\
\text { nutty }\end{array}$ & 3.2 & Kochhar, 1993; Meijboom, 1964 \\
\hline Decanal & $\begin{array}{l}\text { Penetrating, sweet, } \\
\text { waxy, painty }\end{array}$ & 6.7 & Kochhar, 1993; Meijboom, 1964 \\
\hline E,E-2,4-decadienal & Fatty, deep-fried, citrus & 0.18 & Reiners \& Grosh, 1998 \\
\hline & & 2.15 & Kochhar, 1993; Meijboom, 1964 \\
\hline 2-ethylfuran & Sweet, rancid & n.d. & Morales et al., 1997 \\
\hline Hexanoic acid & Sweaty, rancid & 0.7 & Morales et al., 1997 \\
\hline
\end{tabular}

\section{Materials and Methods}

\subsection{Olive Oil Samples}

The study focused on fresh virgin olive oil (crop season, 2010) produced in three different geographical areas in eastern Of Morocco, VOO samples are from olive growers' cooperatives Kenin (Rislane-Tafoughalt), Achajara almoubaraka (Tanacharfi El Aioun) and from Isly (EIG terroir of Oriental, Oujda "Economic Interest Group").

Analysis of volatile compounds was performed in the laboratory of Industrial Biological Chemistry, Faculty of Agricultural Sciences Gembloux, Belgium and oxidative stability analysis was conducted at the same university within the Unit of General and Organic Chemistry. Analysis protocols were provided by the two laboratories.

\subsection{Characterization of Volatile Compounds}

2.2.1 Solid-phase Microextraction (SPME) 
Volatile compounds were analyzed using a solid phase microextraction - gas chromatography (SPME-GC) technique. The sample $(10 \mathrm{ml})$ was placed in a glass vial equipped with a silicon septum and allowed to equilibrate for $30 \mathrm{~min}$ at $30^{\circ} \mathrm{C}$. After the equilibration time, SPME fiber (DVB/CAR/PDMS, Supelco) was inserted through the septum and exposed to the headspace of the sample for $30 \mathrm{~min}$ at $30^{\circ} \mathrm{C}$. After extraction, the fiber was transferred to be desorbed into a GC/MS system. Once sampling was finished, the fiber was reconditioned for $30 \mathrm{~min}$ at the injection port at $250^{\circ} \mathrm{C}$ to re-use.

\subsubsection{Analysis GC/MS}

Solid phase microextraction - gas chromatography - mass spectrometry (SPME-GC-MS) was used to qualitatively analyze volatile compounds using a capillary column HP-5 $(0.25 \mathrm{~mm} * 30 \mathrm{~m} * 0.25 \mathrm{um})$, model Agilent $19091 \mathrm{~J}-433$. The thermal desorption was done in splitless mode. The oven temperature was held at $35^{\circ} \mathrm{C}$ for $5 \mathrm{~min}$, increasing to $85^{\circ} \mathrm{C}$ at a rate of $15^{\circ} \mathrm{C} / \mathrm{min}$ to a final temperature of $300^{\circ} \mathrm{C}$ where it was held for $10 \mathrm{~min}$.

\subsubsection{Identification of Volatile Compounds}

The volatile compounds were identified by comparing their mass spectra with those of the mass spectra library. The retention index (RI) was calculated and compared with RI available in the literature. The RI was determined by injecting a mixture of hydrocarbons containing the homologous series of alkanes (C7-C18) under the same conditions described above.

\subsection{Determination of the Oxidative Stability}

Oxidative stability was evaluated by the Rancimat method (Metrohm model 679, Herisau, Switzerland). Stability was expressed as the induction time (hours), using an oil sample of 2,5g heated to $101^{\circ} \mathrm{C}$ under an air flow of 15 $1 / \mathrm{h}$. The analytical determinations were carried out in duplicate.

\section{Results and Discussion}

\subsection{Volatile Compounds}

A simple chemical analysis is not sufficient to determine the quality of VOO. Indeed, the volatile compounds that develop during the fabrication then during storage are able to modify the odor and flavor of the oil (Kalua, 2007; Prenzler, Robards, \& Bedgood, 2007). Although the sensory properties of virgin olive oil are well known (IOOC, 1996), not too much information about the sensory characteristics of oxidized olive oils is available. For this the identification of compounds responsible for the different sensory attributes would be of great interest in the field of quality control.

For evaluating the flavor profile of VOO after 6 month of storage, oil samples were analyzed using the $\mathrm{SPME} / \mathrm{GC} / \mathrm{MS}$ technique. The results of the qualitative analysis of investigated samples are presented in (Table 2). A total of 84 compounds were detected: including 56 in samples for Kenine association, 31 for Achajara Almoubaraka and 46 in Isly OO. The principal classes of volatile compounds identified were, aldehydes, alcohol, esters, ketones, carboxylic acids and hydrocarbons. 
Table 2. Volatile compounds identified in virgin olive oil aroma detected by GC-MS

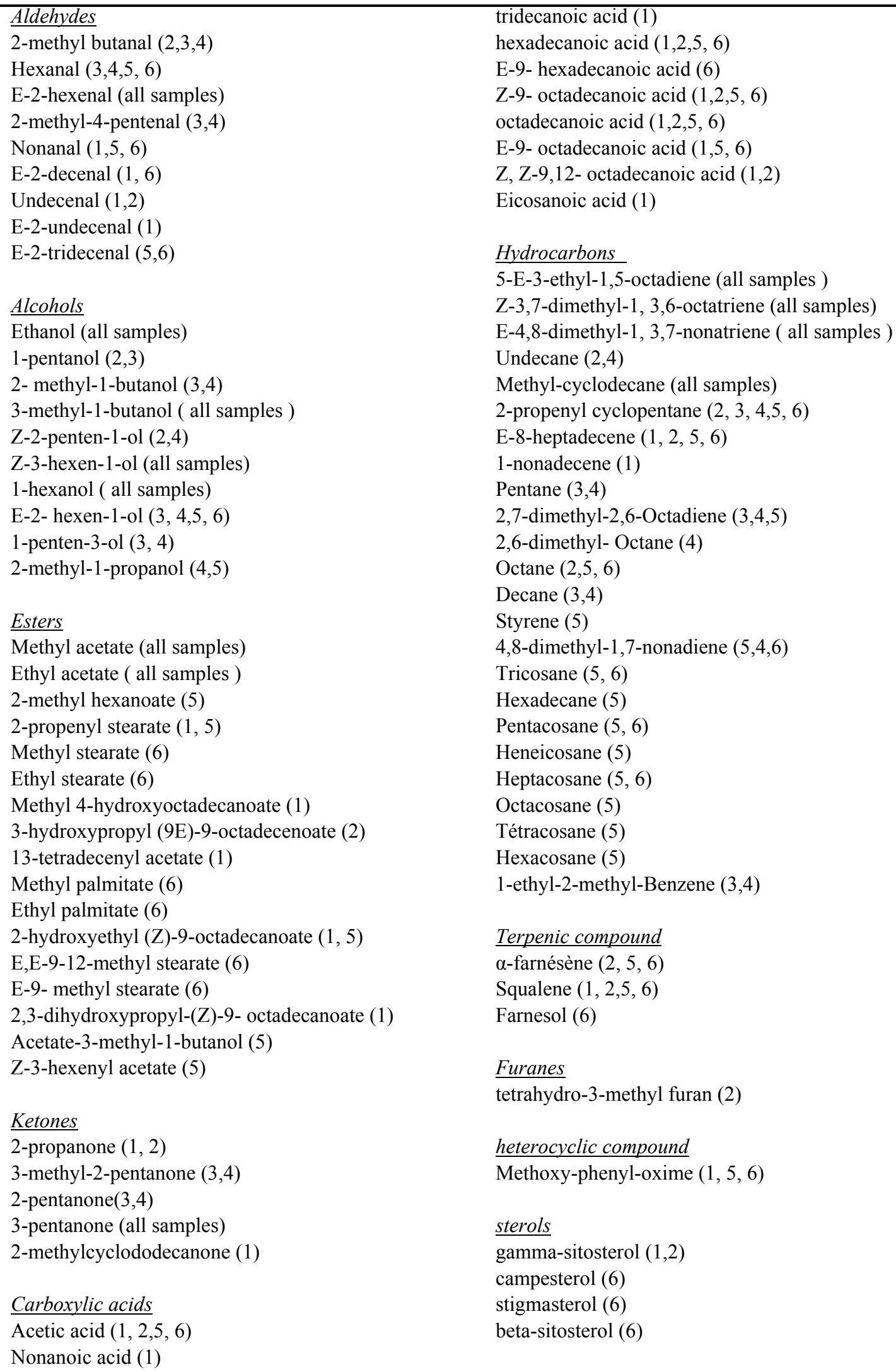

\section{Furanes}

tetrahydro-3-methyl furan (2)

heterocyclic compound

Methoxy-phenyl-oxime $(1,5,6)$

sterols

gamma-sitosterol $(1,2)$

campesterol (6)

stigmasterol (6)

beta-sitosterol (6)

VOO reference number: VOO Isly: 1, 2; -VOO Achajara almoubaraka: 3, 4; -VOO Kenine: 5, 6. 
In Isly (Samples $1 \&$ 2) and Kenine (Samples 5 \& 6) OO samples, the most representative compounds were carboxylic acids which accounted for $59.24 \%$ and $32.42 \%$ respectively (Figures 1 \& 2). These volatile compounds are present only in Isly and Kenine OO. Moreover carboxylic acids are linked to sour and pungent sensations synonymous with sensory defects in olive oil (Kalua, 2007). Vichi et al. (2003b) and Velasco and Dobarganes (2002) reported that higher levels in carboxylic acids are associated with a high oxygen concentration, from storage of $\mathrm{OO}$ in contact with air or frequent opening of oil containers. Kalua et al. (2007) work showed that carboxylic acids with two or three carbon atoms are associated with microbial fermentation and other fruit handling defects, whereas the higher carboxylic acids are linked to oxidative rancidity. Moreover, carboxylic acids such as acetic, hexadecanoic, octadecanoic, Z-9-octadecanoic and E-9-octadecanoic acid were found in Isly and Kenine OO. The most representative carboxylic acid is acetic ranged between $10.04 \%$ and $20.73 \%$ respectively in Kenine and Isly OO. Baccouri et al. (2008) work showed that the level of this volatile compound increased considerably throughout the maturity process and in other studies reported that the presence of acetic acid in the headspaces of VOO might be the result of the process fermentation in the olives. This compound generates the off-flavor: "winey-vinegary" in VOO (Angerosa, 2000; IOOC, 1996; Morales et al., 2005).

In the volatile fraction of Achajara almoubaraka OO (Samples $3 \& 4$ ), the major compounds identified were alcohols (Figures $1 \& 2$ ), ranging around $45.99 \%$. Ethanol is a major component, representing $20.77 \%$ of the total amount, which was related to the fermentation activity before olive oil extraction (Hansen \& Hansen, 1996) and responsible of the sensory descriptor "Alcohol" (Morales et al., 2005). On the other hand, 1-pentanol, associated with the "fruity" aroma (Morales \& Tsimidou, 2000; Aparicio \& Luna, 2002; Morales et al., 2005) and Z-2-penten-1-ol, responsible for the "green" odor notes of VOO aroma (Morales \& Tsimidou, 2000) were identified in the headspaces of Isly $(0.33 \%$ for 1-pentanol and $0.21 \%$ for Z-2-penten-1-ol $)$ and Achajara-almoubaraka ( $0.21 \%$ for 1-pentanol and $0.57 \%$ for Z-2-penten-1-ol) OO samples. On the other hand the volatile alcohol 2-methyl-1-propanol responsible for "green" sensory attributes (Morales\&Tsimidou, 2000) was detected in Achajara-almoubaraka (3.67\%) and Kenine OO (1.05\%). C6 alcohols such as E-2-hexen-1-ol responsible for the sensory descriptor associated with the "ripe fruity, soft" and "green" aromatic sensory notes (Luna, Morales \& Aparicio, 2006; Bendini et al., 2007), it ranged from $0.26 \%$ up to $1.03 \%$, respectively in Kenine and Achajara almoubaraka OO samples. C5 alcohols such as 1-penten-3-ol and 2-methyl-1-butanol, compounds that are linked to "mouldy" and "rancid" defects (Koprivnjak et al., 2000), were found only in Achajara almoubaraka $\mathrm{OO}$ at a low amount $(0.54 \% ; 0.85 \%$ Respectively).

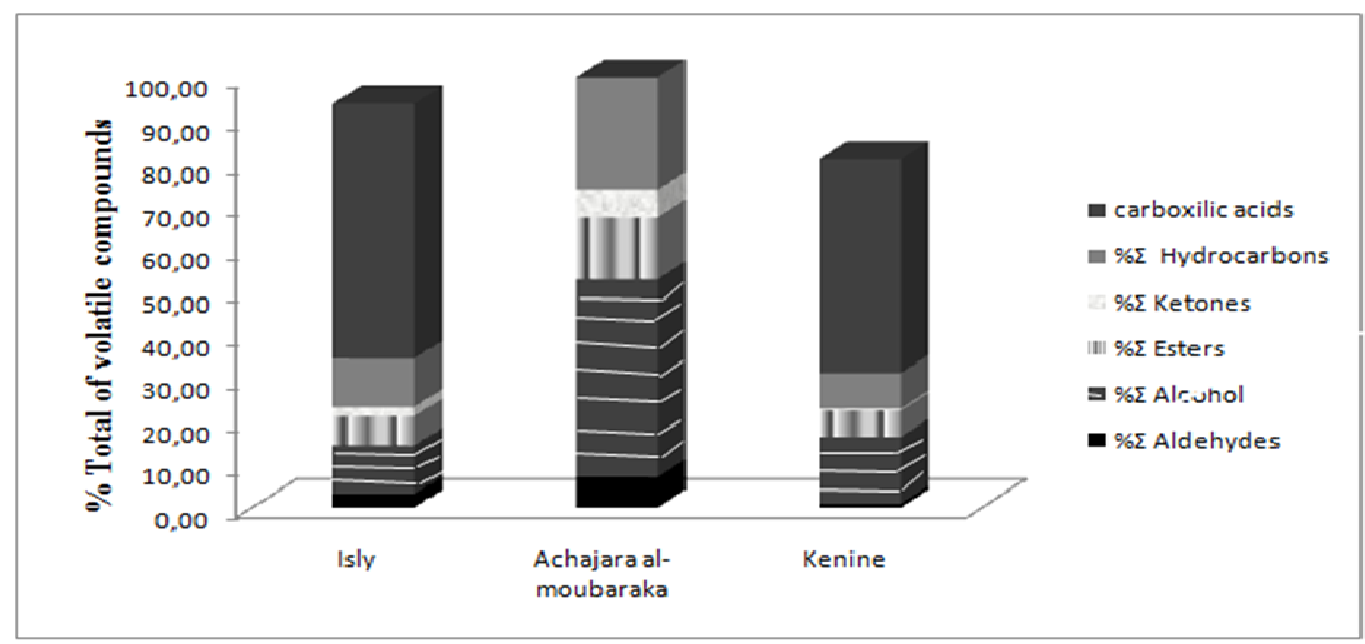

Figure 1. Distribution of carboxylic acids; hydrocarbons; ketones; esters; alcohols and aldehydes in relation to total volatile compounds 


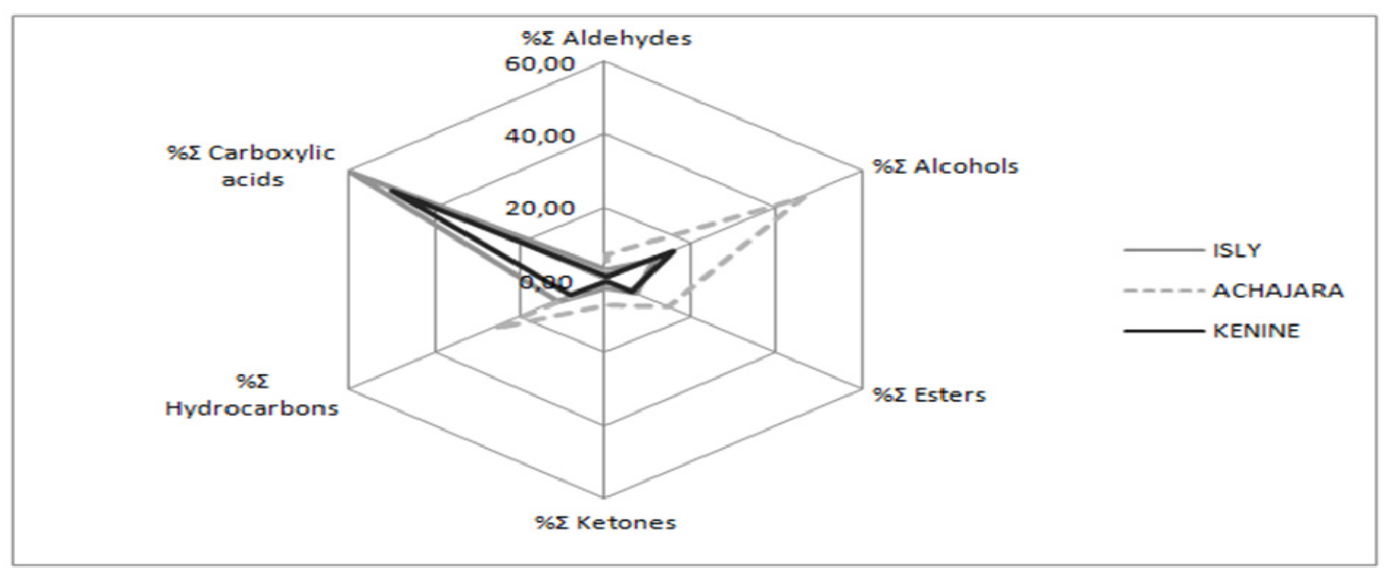

Figure 2. The average of the percentage of volatile compounds for the Isly, Achajara almoubaraka and Kenine

$\mathrm{OO}$

The chemical composition of all the OO headspace was characterized by the presence of 12 volatile compounds in most of the all analyzed samples; however, their proportions were substantially different (Table 3 ), as follows: E-2-hexenal; ethanol; 3-methyl-1-butanol; Z-3-hexen-1-ol; 1-hexanol, methyl acetate; ethyl acetate; 3-pentanone; Z-3,7-dimethyl-1,3,6-octatriene; $\quad$ 5-E-3-ethyl-1,5-octadiene; $\quad$ E-4,8-dimethyl-1,3,7 nonatriene; Methyl-cyclodecane.

Table 3. Percentage of volatile compounds present in all samples

\begin{tabular}{lccc}
\hline & Isly & Achajara almoubaraka & Kenine \\
\hline E-2-hexenal & 1.49 & 1.75 & 0.29 \\
ethanol & 2.62 & 20.77 & 10.63 \\
3-methyl-1-butanol & 0.46 & 0.87 & 0.34 \\
Z-3-hexen-1-ol & 5.46 & 14.12 & 2.35 \\
1-hexanol & 2.72 & 5.41 & 1.48 \\
methyl acetate & 2.04 & 6.30 & 2.17 \\
ethyl acetate & 1.52 & 8.00 & 2.25 \\
3-pentanone & 0.36 & 4.59 & 0.43 \\
5-E-3-ethyl-1,5-octadiene & 1.25 & 2.19 & 0.39 \\
Z-3,7-dimethyl-1, 3,6-octatriene & 0.98 & 1.30 & 0.82 \\
E-4,8-dimethyl-1, 3,7-nonatriene & 1.51 & 1.40 & 0.67 \\
methyl cyclodecane & 4.96 & 8.26 & 3.68 \\
\hline
\end{tabular}

The E-2-hexenal derives from the enzymatic transformation of the fatty acids (Angerosa, D'Alessandro, Basti \& Vito 1998) and mainly contributes to "lawn, banana" and "almond" notes (Angerosa, 2000; Koprivnjak et al., 2002; Morales et al., 2005), given also to extra VOO the typical "green" note, "apple like" and "fruity" (Aparicio \& Luna, 2002; Baccouri et al., 2008; Morales et al., 2005; Reiners \& Grosch, 1998). This compound can be used as quality-freshness markers of VOO (Cavalli, Fernandez, Lizzani-Cuvelier, \& Loiseau, 2004) and which is inversely related to the oxidation degree of virgin olive oil (Vichi et al., 2003b). In fact, E-2-hexenal is produced from Z-3-hexenal by an isomerization factor (Morales \& Aparicio, 1999) with the aid of cis-3: trans-2-enal isomerase (Williams, Salas, Sanchez, \& Harwood, 2000) and it is itself reduced to form E-2-hexen-1-ol (Williams, Morales, Aparicio, \& Harwood, 1998). Isly and Achajara almoubaraka OO samples present higher level of E-2-Hexenal than Kenine OO, accounted for $1.49 \%$; $1.57 \%$; $0.29 \%$ respectively. 
As far as alcohol is concerned, ethanol was higher in the Achajara-almoubaraka and Kenine OO (Table3). The C6 alcohol Z-3-Hexen-1-ol was higher in Isly and Achajara-almoubaraka OO and it ranged from 5.46\% up to $14.12 \%$, respectively. In fact, this compound has been correlated with the "green" sensory perception (Morales \& Aparicio, 1999) and responsible for the "cut grass" odor and could have a role in the enhancement of bitterness (Caporale, Policastro, \& Monteleone, 2004). Bedoukian reported that the cis forms of hexenol were characterized by a more pleasant sensory perception than their corresponding transforms. The high level of 1-Hexanol was found only in Achajara almoubaraka OO (5.41\%); it contributed to "fruity, grassy" and "soft" sensory notes (Gomez-Rico, Salvador, \& Fregapane, 2009). The sensory characterization of hexanol demonstrates that different sensory descriptions exist and in some cases contradictory, for instance "fruit, banana, grassy, soft" and undesirable notes were identified for this same volatile compound (Aparicio \& Morales, 1998). 1-Hexanol can be used to separate cultivars and maturity stages (Prenzler et al., 2007). C5 alcohols such as 3-methyl-1-butanol was present at low amount in the all samples analyzed, this compounds is associated with sensory defects (Angerosa, Mostallino, Basti, \& Vito, 2001; Ranalli, Pollastri, Contento, lannucci, \& Lucera, 2003) "woody, whiskey, sweet" (Morales et al., 2005).

Regarding methyl acetate, contributing to "green" sensory notes (Morales \& Tsimidou, 2000), Achajara almoubaraka OO contained higher levels of this volatile compound compared to other samples (6.30\%). Achajara almoubaraka OO showed also high amount of ethyl acetate (8\%), responsible of sensory descriptor "sticky; sweet" (Morales et al., 2005) and "Crust; crumb" (Bianchi, Careri, Chiavaro, Musci \& Vittadini, 2008). However Di Giovacchino and Serraiocco (1995) have shown that the high concentrations of ethyl acetate were found in olive oils obtained by pressure systems from poor quality olive fruits giving sensory defects such as "fusty" and "winey" defects.

Among the C5 compounds, 3-pentanone was the most important C5 ketone identified in all samples, this compound gives the typical notes associated with "green" (Morales \& Tsimidou, 2000). High amount of this compound characterizes the aroma fraction of Achajara-almoubaraka with $4.59 \%$.

The hydrocarbons like, methyl-cyclodecane; Z-3,7-dimethyl-1,3,6-octatriene; 5-E-3-ethyl-1,5-octadiene and E-4,8-dimethyl-1,3,7-nonatriene were detected in the all aroma fractions of the analyzed OO. However Jung, De Ropp and Ebeler (2000) reported that the presence of hydrocarbons, proteins and other minor components in OO can decrease the aroma intensity through sorption, binding and formation of intermolecular complexes. Moreover the role of these components in the definition of flavor is not clear. In fact, in the literature, only very few papers (Bentivenga, D’Auria, De Luca, De Bona, \& Mauriello, 2001; Vichi et al., 2003b) report the presence of these compounds, which could play a very important role in the fragrance of this valuable food.

Finally, in each of the analyzed $\mathrm{OO}$ samples there were compounds which were identified but not found in others (Table2). They are as follows:

Aldehydes: Hexanal is among the main volatile components of OO (Williams, Morales, Aparicio \& Harwood, 1998). It is present in Achajara-almoubaraka and Kenine OO at a low amount (5.06\%; $0.25 \%$ respectively). The amount of hexanal is due to both autoxidation and the lipoxygenase cascade (through the formation of 13-LOOH) (Vichi et al., 2003b). The high amounts of hexanal, often related to a sweet (Morales \& Tsimidou, 2000) green and apple sensory note (Morales \& Aparicio, 1999; Koprivnjak et al., 2002).

Nonanal and E-2-decenal were identified at low amount in the headspace of Isly $(0.57 \%$ for nonanal and $0.5 \%$ for E-2-decenal) and Kenine OO (0.15\% for nonanal and 0.18\% for E-2-decenal). In fact Bendini et al. (2010) reported that these two compounds with the E-2-heptenal are the most frequently used volatile markers of oxidation of VOO during storage. These compounds are characterized by low odor threshold $(150,100$ and 5 $\mu \mathrm{g} / \mathrm{kg}$, respectively) and by negative off-flavors namely "oxidized", fatty and fish, that strongly contribute to the rancid defect perceived by assessors. Kanavouras, Hernandez-Munoz, Coutelieris (2004) carried out a storage study. They could select a group of volatiles such as hexanal, E-2-heptenal, nonanal, and E-2-decenal, highly correlated with oxidation in packaged extra virgin olive oil under various storage conditions for one year (glass/ $\mathrm{PET} / \mathrm{PVC}$ bottles; $15^{\circ} / 30^{\circ} / 40^{\circ} \mathrm{C}$ temperature; light or dark conditions).

Esters: Esters are compounds associated with fruity sensory notes (Aparicio \& Luna, 2002; Luna et al., 2006). The presence of C6 esters in virgin olive oils contributes to the positive sensory notes "sweet", "fruity" and "green leaf" (Inarejos-Garcia et al., 2010b), however Kenine OO samples showed a low concentration in Z-3-hexenyl acetate $(0.27 \%)$. This could be due to the fact that the activity of the alcohol acyl transferase involved in the biogeneration of C6 esters is low (Olías, Pérez, Ríos \& Sanz, 1993; Ridolfi, Terenziani, Patumi, $\&$ Fontanazza, 2002). Except the methyl and ethyl acetate, which were present in all samples, the majority of the 
esters were identified only in Isly and Kenine OO at different percentages. Furthermore, Achajara almoubaraka OO was rich in ethers (14.31\%) compared to other oils analyzed (Figure 2).

Ketones: C5 ketones such as 2-pentanone, increase during storage (Cavalli et al., 2004), this compound does not result from the lipoxygenase pathway by enzymatic actions, but from homolytic cleavage of 13-hydroperoxides (Angerosa, 2002) to the detriment of $\mathrm{C} 6$ aldehyde and alcohol formation. This compound was present in the headspace of the Achajara almoubaraka $\mathrm{OO}(1.12 \%)$.

Hydrocarbons: The hydrocarbon octane (sweet sensory characteristics) is due to autoxidation reactions (Morales et al., 2005; Morales et al., 1997) and it was the marker for storage in the light (Kalua et al., 2006). Low amounts of this compound were found in the headspaces of VOO Isly (0.4\%) and Kenine (0.53\%). Morales et al. (2005) reported that this volatile with other compounds which are also due to autoxidation reaction, are responsible for virgin olive oil off-flavors.

\subsection{Oxidative Stability}

Stability to oxidation is an important property of olive oil, VOO is considered to be resistant to oxidation because of its low content of polyunsaturated fatty acids and the presence of natural antioxidants. The oxidative stabilities of the oils were measured as the induction time in response to forced oxidation, and they are shown in (Table 4). Oxidative stability of the VOOs analyzed varied according to the origin. It ranged from a minimum of 38.75-40.58h (Kenine) and 46.05-46.75h (Isly) to a maximum of 50.95-62.55h (Achajara almoubaraka). This difference of oxidative stability between the different VOOs analyzed could be explained by the different amounts of phenolic compounds (Lerma-García, Simó-Alfonso, Bendini, \& Cerretani, 2009) and other natural antioxidants.

Compared to Achajara almoubaraka OO, Isly and Kenine OO, had lower stability values, their potential oxidative susceptibility was therefore much higher than Achajara almoubaraka. Table 4 indicates that Isly and Kenine OO showing a higher value for compounds responsible for off-flavor (COF). Aparicio, Roda, Albi \& Gutierrez (1999) reported that high values of stability indirectly mean a low level of rancidity and hence low presence of the undesirable sensory descriptors such as rancidity. Nonanal and E-2-decenal are the most frequently used volatile markers of oxidation of virgin olive oil during storage (Bendini et al., 2010). These are characterized by low odour threshold (150 and $100 \mu \mathrm{g} \mathrm{kg}-1$, respectively) and by negative off-flavours namely oxidized. These compounds were present in Isly and Kenine OO samples at a low amounts (Table 4). We have also noted that the oil having a low value of the oxidative stability (Isly \& Kenine) were dominated by carboxylic acids, whereas carboxylic acids dominate the volatile compounds in oils stored in oxygenrich environments, and polymeric volatile compounds are produced at elevated temperatures. These volatile compounds, from oxidation, modify the sensory quality of olive oils (Vichi et al., 2003 a).

Table 4. Rancimat induction periode (hours) at $101^{\circ} \mathrm{C}$ and amount (\%) of volatils compounds reponsible for off-flavor

\begin{tabular}{ccccccccccccc}
\hline & OS & Oct & Non & E-2-dec & Und & $\boldsymbol{\Sigma}$ carb & 1-pen & 2-met & 3-met & Eth & Eth.ac & $\begin{array}{c}\boldsymbol{\Sigma} \\
\text { COF }\end{array}$ \\
\cline { 2 - 11 } $\mathbf{1}$ & 46.05 & - & 0.57 & 1.5 & 0.5 & 64.83 & - & - & 0.44 & 1.88 & 1.38 & 71.1 \\
$\mathbf{2}$ & 46.75 & 0.4 & - & - & 0.8 & 53.65 & - & - & 0.48 & 3.35 & 1.66 & 60.34 \\
$\mathbf{3}$ & 50.95 & - & - & - & - & 0 & 0.79 & 1.22 & 0.99 & 19.95 & 9.18 & 30.91 \\
$\mathbf{4}$ & 62.55 & - & - & - & - & 0 & 0.62 & 0.48 & 0.76 & 21.58 & 6.82 & 30.26 \\
$\mathbf{5}$ & 38.75 & 0.88 & 0.26 & - & - & 47.69 & - & - & 0.58 & 17.7 & 3.87 & 70.98 \\
$\mathbf{6}$ & 40.85 & 0.17 & 0.05 & 0.2 & - & 51.71 & - & - & 0.41 & 3.54 & 0.61 & 56.69 \\
\hline
\end{tabular}

VOO reference number: VOO Isly: 1, 2; -VOO Achajara almoubaraka: 3, 4; -VOO Kenine: 5, 6.

OS: Oxidative stability; Oct: Octane; Non: Nonanal; Und: Undecenal; carb: carboxilic acids; 1-pen: 1-penten-3-ol; 2-meth: 2-methyl-1-butanol; 3-meth: 3-methyl-1-butanol. Eth: ethanol; eth. ac: ethyl acetate; $\Sigma$ COF: Sum of the compounds responsible for off-flavor. 


\section{Conclusion}

Analysis of the VOOs produced in the eastern of Morocco by SPME enabled us to identify 84 compounds, represented by different chemical classes. The volatile profiles of Isly and Kenine OO were similar. Most of the volatile compounds consist of carboxylic acids. There are volatile compounds that are formed in oxidized olive oil regardless of the external conditions. These results indicate that the volatile profiles of Isly and Kenine OO were distinctly different from those of Achajara almoubaraka characterized by significantly higher levels in Alcohols. It should be noted that the high concentration volatile compounds are not necessarily the major contributors of odor. For instance, Reiners and Grosch (1998) reported a concentration of $6770 \mu \mathrm{g} / \mathrm{g}$ for trans-2-hexenal with an odor activity value of 16 whereas 1-penten-3-one with a much lower concentration of 26 $\mu \mathrm{g} / \mathrm{g}$ had a higher odor activity value of 36 . The results of the oxidative stability have also demonstrated a difference between the analyzed VOOs, in fact compared to Achajara almoubaraka OO, Isly and Kenine OO, had lower stability values, and a higher value of COF's sum. However, in the analyzed samples, except carboxylic acids, the amounts of compounds formed from oxidation reactions were low (Table 3). Analysis of volatile compounds by SPME must be completed by a GC / olfactometry to determine the intensity of sensory descriptors for each compound and selected compounds that have a significant odor impact contributing to the aroma of oils olive studied.

\section{References}

Angerosa, F. (2000). Sensory quality of olive oils: Handbook of olive oil, Analysis and properties, In Harwood J., Aparicio R (Eds.) (pp. 355-372). Gaithersburg, MD, USA: Aspen Publications Inc.

Angerosa, F. (2002). Influence of volatile compounds on virgin olive oil quality evaluated by analytical approaches and sensor panels. European Journal of Lipid Science and Technology, 104, 639-660. http://dx.doi.org/10.1002/1438-9312(200210)104:9/10<639::AID-EJLT639>3.0.CO;2-U

Angerosa, F., \& Basti, C. (2001). Olive oil volatile compounds from the lipoxygenase pathway in relation to fruit ripeness. Italian Journal of Food Science, 13(4), 421-428.

Angerosa, F., Basti, C., \& Vito, R. (1999). Virgin olive oil volatile compounds from lipoxygenase pathway and characterization of some Italian cultivars. Journal of Agricultural and Food Chemistry, 47, 836-839. http://dx.doi.org/10.1021/jf980911g

Angerosa, F., D’Alessandro, N., Basti, C., \& Vito, R. (1998). Biogeneration of volatile compounds in virgin olive oil: Their evolution in relation to malaxation time. Journal of Agricultural and Food Chemistry, 46(8), 2940-2944. http://dx.doi.org/10.1021/jf970641m

Angerosa, F., Mostallino, R., Basti, C., \& Vito, R. (2000). Virgin olive oil odour notes: their relationships with volatile compounds from the lipoxygenase pathway and secoiridoid compounds. Food Chemistry, 68, 283-287. http://dx.doi.org/10.1016/S0308-8146(99)00189-2

Angerosa, F., Mostallino, R., Basti, C., \& Vito, R. (2001). Influence of malaxation temperature and time on the $\begin{array}{lllll}\text { quality of virgin olive oils. Food Chemistry, } & 72(1), & 19-28 .\end{array}$ http://dx.doi.org/10.1016/S0308-8146(00)00194-1

Aparicio, R., \& Morales, M-T. (1998). Characterization of olive ripeness by green aroma compounds of virgin olive oil. Journal of Agricultural and Food Chemistry, 46(3), 1116-1122. http://dx.doi.org/10.1021/j9970540o

Aparicio, R., \& Luna G. (2002). Characterisation of monovarietal virgin olive oils. European Journal of Lipid $\begin{array}{llll}\text { Science } \quad \text { and } & \text { Technology, }\end{array}$ http://dx.doi.org/10.1002/1438-9312(200210)104:9/10<614::AID-EJLT614>3.0.CO;2-L

Aparicio, R., Roda, L., Albi, M. A., \& Gutierrez, F. (1999). Effect of Various Compounds on Virgin Olive Oil Stability Measured by Rancimat. Journal of Agricultural and Food Chemistry, 47, 4150-4155. http://dx.doi.org/10.1021/jf9812230

Baccouri, O., Bendini, A., Cerretani, L., Guerfel, M., Baccouri, B., Lercker, G., ... Ben Miled, D. D. (2008). Comparative study on volatile compounds from Tunisian and Sicilian monovarietal virgin olive oils. Food Chemistry, 111, 322-328. http://dx.doi.org/10.1016/j.foodchem.2008.03.066

Ben Temime, S., Campeol, E., Cioni, P-L., Daoud, D., \& Zarrouk, M. (2006).Volatile compounds from Chétoui olive oil and variations induced by growing area. Food Chemistry, 99, 315-325. http://dx.doi.org/10.1016/j.foodchem.2005.07.046 
Bendini, A., Cerretani, L., Carrasco-Pancorbo, A., Gómez-Caravaca, A. M., Segura-Carretero, A., Fernández-Gutiérrez, A., \& Lercker, G. (2007). Phenolic molecules in virgin olive oils: a survey of their sensory properties, health effects, antioxidant activity and analytical methods. An overview of the last decade. Molecules, 12, 1679. http://dx.doi.org/10.3390/12081679

Bendini, A., Cerretani, L., Salvador, M-D., Fregapane, G., \& Lercker, G. (2010). Stability of the sensory quality of virgin olive oil during storage an overview. Italian Food \& Beverage Technology - LX. pp. 5-18.

Bentivenga, G., D'Auria, M., De Luca, E., De Bona, A., \& Mauriello, G. (2001). The use of SPME-GC-MS in the analysis of flavor of virgin olive oil. Riv. Ital. Sostanze Grasse, 78, 157-162.

Bianchi, F., Careri, M., Chiavaro, E., Musci, M., \& Vittadini, E. (2008). Gas chromatographic-mass spectrometric characterisation of the Italian Protected Designation of Origin "Altamura" bread volatile profile. Food Chemistry, 110, 787-793. http://dx.doi.org/10.1016/j.foodchem.2008.02.086

Caporale, G., Policastro, S., \& Monteleone, E. (2004). Bitterness enhancement induced by cut grass odourant (cis-3-hexen-1-ol) in a model olive oil. Food Quality and Preference, 15, 219-227. http://dx.doi.org/10.1016/S0950-3293(03)00061-2

Cavalli, J. f., Fernandez, X., Lizzani-Cuvelier, L., \& Loiseau, A. M. (2004). Characterization of volatile compounds of French and Spanish virgin olive oils by HS-SPME: identification of quality freshness markers. Food Chemistry, 88, 151-157. http://dx.doi.org/10.1016/j.foodchem.2004.04.003

Dhifi, W., Angerosa, F., Serraiocco, A., Oumar, I., Hamrouni, I., \& Marzouk, B. (2005). Virgin olive oil aroma: Characterization of some Tunisian cultivars. Food Chemistry, 93, 697-701. http://dx.doi.org/10.1016/j.foodchem.2004.12.036

Di Giovacchino, L., \& Serraiocco, A. (1995). Influence of processing methods of olives on the composition of the headspace of oils. Riv Ital Sostanze Grasse, 72, 443-450.

Diego, 1. Gonzalez, G., \& Aparicio, R. (2010). Research in Olive Oil: Challenges for the Near Future. J. Agric. Food Chem., 58, 12569-12577.

Escuderos, M. E., Uceda, M., Sánchez, S., \& Jiménez, A. (2007). Instrumental technique evolution for olive oil sensory analysis. European Journal of Lipid Science and Technology, 109, 536-546. http://dx.doi.org/10.1002/ejlt.200600239

Faria, S. L., Cárdenas, S., G-Mesa, J. A., Hernández, A. F., \& Valcárcel, M. (2007). Quantification of the Intensity of Virgin Olive Oil Sensory Attributes by Direct Coupling Headspace-Mass Spectrometry and Multivariate Calibration Techniques. Journal of Chromatography A, 1147, 144-152. http://dx.doi.org/10.1016/j.chroma.2007.02.107

Garcia-Gonzalez, D. L., Aparicio-Ruiz, R., \& Aparicio, R. (2009). Gourmet and Health-Promoting Oils. In R. A. Moreaou, A. Kamal-Eldin (Eds.) (pp. 33-72.) AOCS Press: Champaign, IL.

Gomes da Silva, M. D. R., Costa Freitas, A. M., Cabrita, M. J. B., \& Garcia, R. (2012). Olive Oil Composition: Volatile Compounds: Constituents quality health properties and bioconversions, Boskou D (Ed.), pp. 17-46.

Gomez-Rico, A., Salvador, M. D., \& Fregapane, G. (2009). Virgin olive oil and olive fruit minor constituents as affected by irrigation management based on SWP and TDF as compared to ETc in medium-density young olive orchards (Olea europaea L. cv. Cornicabra and Morisca). Food Research International, 42(8), 1067-1076. http://dx.doi.org/10.1016/j.foodres.2009.05.003

Gomez-Rico, A., Salvador, M. D., La Greca, M., \& Fregapane, G. (2006). Phenolic and volatile compounds of extra virgin olive oil (Olea europaea L. cv. Cornicabra) with regard to fruit ripening and irrigation management. Journal of Agricultural and Food Chemistry, 54, 7130-7136. http://dx.doi.org/10.1021/jf060798r

Guth, H., \& Grosh, W. (1991). A comparative study of the potent odorants of different virgin olive oils. Fat Science and Technology, 93, 335-339.

Ha, T. J., Nihei, K. I., \& Kubo, I. (2004). Lipoxygenase inhibitory activity of octyl gallate. Journal of Agricultural and Food Chemistry, 52(10), 3177-3181. http://dx.doi.org/10.1021/jf034925k

Haddada, M. F., Manai, H., Daoud, D., Fernandez, X., Lizzani-Cuvelier, L., \& Zarrouk, M. (2007). Profiles of volatile compounds from some monovarietal Tunisian virgin olive oils. Comparison with French PDO. Food Chemistry, 103, 467-476. http://dx.doi.org/10.1016/j.foodchem.2006.08.023 
Hansen, Å., \& Hansen, B. (1996). Flavour of sourdough wheat bread crumb. Zeitschrift fur Lebensmittel Untersuchung und Forschung A, 202, 244-249. http://dx.doi.org/10.1007/BF01263548

Inarejos-Garcia, A. M., Gómez-Rico, A., Salvador, M. D., \& Fregapane, G. (2010 a). Effect of preprocessing olive storage conditions on virgin olive oil quality and composition. Journal of Agriculture and Food Chemistry, 58, 4858-4865. http://dx.doi.org/10.1021/jf902486f

Inarejos-Garcia, A. M., Santacatterina, M., Salvador, M. D., Fregapane, G., \& Gómez-Alonso, S. (2010 b). PDO virgin olive oil quality-Minor components and organoleptic evaluation. Food Research International, 43, 2138-2146. http://dx.doi.org/10.1016/j.foodres.2010.07.027

IOOC. (1996). International Olive Oil Council Organoleptic evaluation of virgin olive oil. COI/T.20/ Document N.15/Rev.1. Madrid.

Jung, D. M., De Ropp, J. S., \& Ebeler, S. E. (2000). Study of interactions between food phenolics and aromatic flavors using one- and twodimensional H-1 NMR spectroscopy. Journal of Agricultural and Food Chemistry, 48(2), 407-412. http://dx.doi.org/10.1021/jf9906883

Kalua, C. M., Allen, M. S., Bedgood, D. R., Bishop, A. G., Prenzler, P. D., \& Robards, K. (2007). Olive oil volatile compounds, flavour development and quality: A critical review. Food Chemistry, 100, 273-286. http://dx.doi.org/10.1016/j.foodchem.2005.09.059

Kalua, C. M., Bedgood, D. R., Bishop, A. G., \& Prenzler, P. D. (2006). Discrimination of storage conditions and freshness in virgin olive oil. J. Agric. Food Chem., 54, 7144. http://dx.doi.org/10.1021/jf061038j

Kanavouras, A., Hernandez-Munoz, P., \& Coutelieris, F. A. (2004). Shelf life predictions for packaged olive oil using $\mathrm{fl}$ avor compounds as markers. Eur. Food Res. Technol., 219, 190. http://dx.doi.org/10.1007/s00217-004-0933-2

Kiritsakis, A. K., Nanos, G. D., Polymenoupoulos, Z., Thomai, T., \& Sfakiotakis, E. Y. (1998). Effect of fruit storage conditions on olive oil quality. Journal of the American Oil Chemists Society, 75, 721-724. http://dx.doi.org/10.1007/s11746-998-0212-7

Kochhar, S. P. (1993). Oxidative pathways to the formation of off-flavours. In Food Traints and Off-Flavours, Edited by Saxby M-J. London: Blackie Academic \& Professional, ISBN: 075140263 X 0442308639 (USA), pp. 150-201.

Koprivnjak, O., Conte, L., \& Totis, N. (2002): Influence of olive fruit storage in bags on oil quality and composition of volatile compounds. Olive Fruit Storage in Bags, Food Technol. Biotechnol, 40(2), 129-134.

Koprivnjak, O., Procida, G., \& Zelinotti, T. (2000). Changes in the volatile components of virgin olive oil during fruit storage in aqueous media. Food Chemistry, 70(3), 377-384. http://dx.doi.org/10.1016/S0308-8146(00)00107-2

Lerma-García, M. J., Simó-Alfonso, E. F., Bendini, A., \& Cerretani, L. (2009). Metal oxide semiconductor sensors for monitoring of oxidative status evolution and sensory analysis of virgin olive oils with different phenolic content. Food Chemistry, 1-7.

Luna, G., Morales, M. T., \& Aparicio, R. (2006). Changes induced by UV radiation during virgin olive oil storage. J. Agric. Food Chem., 54, 4790. http://dx.doi.org/10.1021/jf0529262

Mejboom, P. W. (1964). Relationship between molecular structure and flavour perceptibility of aliphatic aldehydes. J. Am Oil Chem Soc., 41, 326-328. http://dx.doi.org/10.1007/BF02667030

Morales, M. T., \& Aparicio, R. (1999). Effect of extraction conditions on sensory quality of virgin olive oil. Journal of the American Oil Chemists Society, 76(3), 295-300. http://dx.doi.org/10.1007/s11746-999-0234-9

Morales, M. T., Alonso, M. V., Rios, J. J., \& Aparicio, R. (1995). Virgin olive oil aroma: relationships between volatile compounds and sensory attributes by chemometrics. Journal of Agricultural and Food Chemistry, 43, 2925-2931. http://dx.doi.org/10.1021/jf00059a029

Morales, M. T., Calvente, J. J., \& Aparicio, R. (1996). Influence of olive ripeness on the concentration of green aroma compounds in virgin olive oil. Flavour and Fragrance Journal, 11, 171-178. http://dx.doi.org/10.1002/(SICI)1099-1026(199605)11:3<171::AID-FFJ563>3.0.CO;2-2

Morales, M. T., Luna, G., \& Aparicio, R. (2005). Comparative study of virgin olive oil sensory defects. Food Chemistry, 91(2), 293-301. http://dx.doi.org/10.1016/j.foodchem.2004.06.011 
Morales, M. T., Rios, J. J., \& Aparicio, R. (1997). Changes in the volatile composition of virgin olive oil during oxidation: Flavors and off-flavors. Journal of Agricultural and Food Chemistry, 45, 2666-2673. http://dx.doi.org/10.1021/jf960585+

Morales, M. T., \& Tsimidou, M. (2000). The role of volatile compounds and polyphenols in olive oil sensory quality, Analysis and properties, In Harwood J., \& Aparicio R. (Eds.) (pp. 399-458). Gaithersburg, MD, USA: Aspen Publications Inc. ISBN: 0-8342-1633-7.

Olías, J. M., Pérez, A. G., Ríos, J. J., \& Sanz, L. C. (1993). Aroma of virgin olive oil Biogenesis of the green odor notes. Journal of Agricultural and Food Chemistry, 41, 2368-2373. http://dx.doi.org/10.1021/jf00036a029

Prenzler, P., Robards, K., \& Bedgood, D. (2007). Quality Enhancement of Australian Extra Virgin Olive Oils, A report for the Rural Industries Research and Development Corporation. ISBN: 1-74151-398 7/ISSN: $1440-6845$.

Psomiadou, E., \& Tsimidou, M. (2001). Pigments in Greek virgin olive oils: Occurrence and levels. $J$. of the Science of Food and Agriculture, 81, 640-647. http://dx.doi.org/10.1002/jsfa.859

Ranalli, A., Pollastri, L., Contento, S., lannucci, E., \& Lucera, L. (2003). Effect of olive paste kneading process time on the overall quality of virgin olive oil. European Journal of Lipid Science and Technology, 105(2), 57-67. http://dx.doi.org/10.1002/ejlt.200390018

Reiners, J., \& Grosch, W. (1998). Odorants of virgin olive oils with different flavor profiles. Journal of Agricultural and Food Chemistry, 46(7), 2754-2763. http://dx.doi.org/10.1021/jf970940b

Ridolfi, M., Terenziani, S., Patumi, M., \& Fontanazza, G. (2002). Characterization of the lipoxygenases in some olive cultivars and determination of their role in volatile compounds formation. Journal of Agricultural and Food Chemistry, 50, 835-839. http://dx.doi.org/10.1021/jf0109118

Servili, M., Selvaggini, R., Esposto, S., Taticchi, A., Montedoro G. F., \& Morozzi G. (2004). Health and sensory properties of virgin olive oil hydrophilic phenols: agronomic and technological aspects of production that affect their occurrence in the oil. J. Chrom. A., 1054, 113.

Solinas, M., Angerosa, F., \& Cucurachi, A. (1987). Connessione tra I prodotti di neoformazione ossidativa delle sostanze. Riv. Ital. Sostanze Grasse, 64, 137.

Ullrich, F., \& Grosch, W. (1988). Identification of the most intense odor compounds formed during autoxidation of methyl linolenate at room temperature. J. Am. Oil Chem. Soc., 65, 1313. http://dx.doi.org/10.1007/BF02542413

Velasco, J., \& Dobarganes, C. (2002). Oxidative stability of virgin olive oil. European Journal of Lipid Science and Technology, 104(9-10), 661-676. http://dx.doi.org/10.1002/1438-9312(200210)104:9/10<661::AID-EJLT661>3.0.CO;2-D

Venkateshwarlu, G., Let, M. B., Meyer, A. S., \& Jacobsen, C. (2004). Modeling the sensory impact of defined combinations of volatile lipid oxidation products on fishy and metallic off-flavors. Journal of Agricultural and Food Chemistry, 52(6), 1635-1641. http://dx.doi.org/10.1021/jf0351321

Vichi, S., Castellote, A. I., Pizzale, L., Conte, L. S., Buxaderas, S., \& Lopez-Tamames, E. (2003b). Analysis of virgin olive oil volatile compounds by headspace solid-phase microextraction coupled to gas chromatography with mass spectrometric and flame ionization detection. Journal of Chromatography A, 983, 19-33. http://dx.doi.org/10.1016/S0021-9673(02)01691-6

Vichi, S., Pizzale, L., Conte, L-S., Buxaderas, S., \& Lopez-Tamames, E. (2003a). Solid-phase microextraction in the analysis of virgin olive oil volatile fraction: Modifications induced by oxidation and suitable markers of oxidative status. Journal of Agriculture and Food Chemistry, 51, 6564-6571. http://dx.doi.org/10.1021/jf030268k

Villière, A., \& Genot C. (2006). Approche physico-chimique et sensorielle de l'oxydation des lipides en émulsions (Prix de thèse de l'AFECG) (INRA - Unité biopolymères, interactions, assemblages,).

Williams, M., Morales, M. T., Aparicio, R., \& Harwood, J. L. (1998). Analysis of volatiles from callus cultures $\begin{array}{lllll}\text { of olive } \quad \text { olea } & \text { europaea. } & \text { Phytochemistry, } & 47(7), & 1253-1259 .\end{array}$ http://dx.doi.org/10.1016/S0031-9422(97)00730-9

Williams, M., Salas, J. J., Sanchez, J., \& Harwood, J. L. (2000). Lipoxygenase pathway in olive callus cultures (Olea europaea). Phytochemistry, 53(1), 13-19. http://dx.doi.org/10.1016/S0031-9422(99)00468-9 